\title{
A Dynamic Panel Analysis of the Profitability of Australian Tax Entities*
}

\author{
Simon Feeny, Mark N. Harris ${ }^{\dagger}$ and Joanne Loundes \\ Melbourne Institute of Applied Economic and Social Research \\ The University of Melbourne \\ †'and Central European University, Budapest, Hungary
}

Melbourne Institute Working Paper No. 22/00

ISSN 1328-4991

ISBN $073401502 X$

November 2000

\begin{abstract}
* This paper is the result of work being undertaken as part of a collaborative research program entitled 'The Performance of Australian Enterprises: Innovation, Productivity and Profitability'. This project is generously supported by the Australian Research Council and the following collaborative partners: The Australian Tax Office, Commonwealth Office of Small Business, IBIS Business Information Pty Ltd, Productivity Commission, and Victorian Department of State Development. The views expressed in this paper represent those of the authors and not necessarily the views of the collaborative partners. We are grateful to David Prentice and John Creedy for helpful comments.
\end{abstract}

Melbourne Institute of Applied Economic and Social Research

The University of Melbourne

Victoria 3010 Australia

Telephone (03) 83445330

Fax (03) 83445630

Email melb.inst@iaesr.unimelb.edu.au

WWW Address http://www.melbourneinstitute.com 


\begin{abstract}
This paper investigates the determinants of profitability of Australian tax entities over the period 1993/94 to 1996/97 for each of 91 three-digit ANZSIC industries. The theoretical model is based on that of Cowling and Waterson (1976). However, it is augmented by the inclusion of lagged profitability to allow for habit persistence in entity profitability. The socalled operational Wansbeek-Bekker estimator is used to control for endogeneity of this lagged dependent variable, whilst simultaneously controlling for observed and unobserved entity heterogeneity. Aggregate results suggest that profitability in the previous year, entity capital intensity, and barriers to entry have the expected positive association with current profitability measured by the price-cost margin. Entity market share-and to a lesser extent concentration—are found to have a U shaped relationship with profitability.
\end{abstract}




\section{Contents}

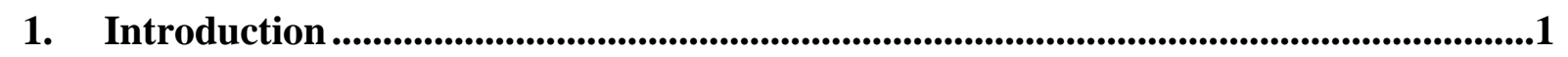

2. $\quad$ Structure-Conduct-Performance and Profitability............................................................2

3. The Australian Tax Office Tax Return Database ...........................................................6

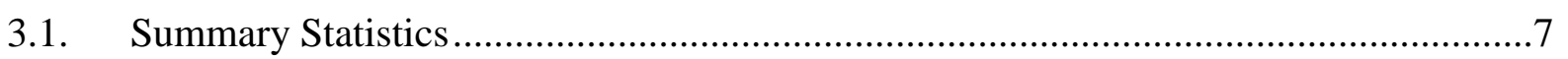

4. $\quad$ Estimating Profitability in the Structure-Conduct-Performance Framework ..........8

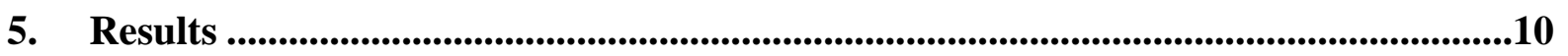

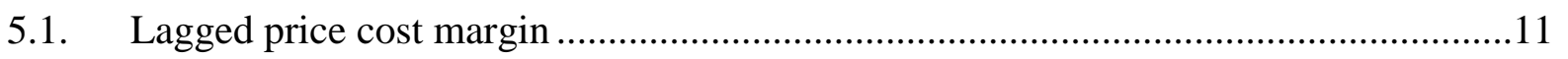

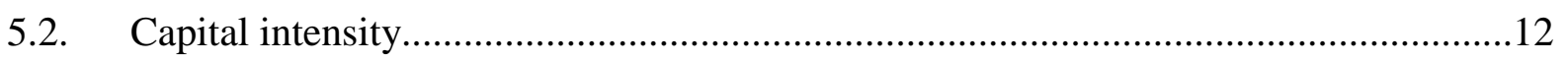

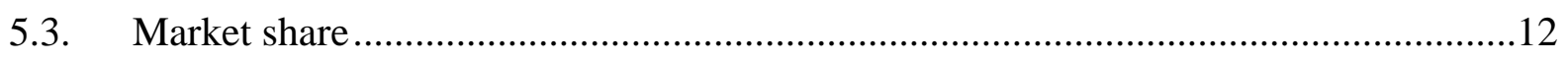

5.4. $\quad$ Concentration ........................................................................................................... 13

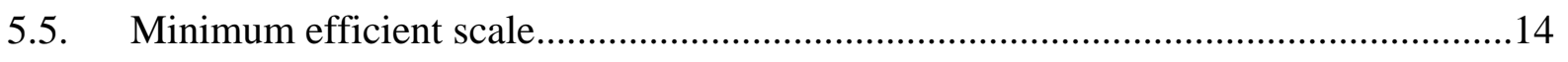

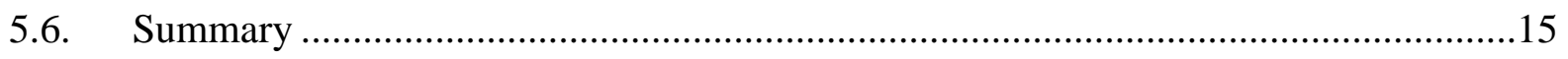

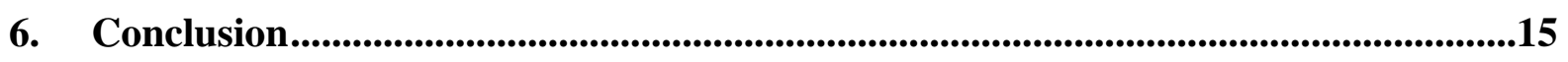





\section{Introduction}

The aim of this paper is to estimate the profitability of Australian tax entities using the structure-conduct-performance framework and a unique data set containing tax return records of Australian business entities. There are two major differences between this dataset and firm level datasets. The population of Australian tax entities made available by the Australian Tax Office (ATO) enables the analysis to be undertaken at the 3-digit ANZSIC industry level. If profitability varies across industries, and the determinants of profitability also vary by industry, it is important to ensure that analysis is carried out on an industry-by-industry basis. This represents a departure from most previous studies, which often include industry dummy variables to allow for changes in firm profitability between industries, but coefficients on the determinants of profitability are restricted to be constant across industries. The finding that the determinants of entity profitability do vary widely across industries validates the approach adopted in this paper. The second difference is that financial information is available at the entity level. Firms commonly undertake a wide range of activities and operate in a number of different industries. A tax entity may be used to report a specific activity of a firm within a well-defined industry and therefore closer to a 'line of business'. Market structure variables such as market share and concentration are therefore likely to have a greater degree of accuracy when calculated using entity level data rather than from a firm level dataset.

The Wansbeek-Bekker dynamic panel estimator is utilised to analyse the tax return information because one of its strengths is that it removes any unobserved heterogeniety, leaving only estimates of the 'true' effect of market structure on profitability. The use of a panel-as opposed to a time-series or cross-section model-addresses a number of issues that are important in considering entity profitability. Firstly, both observed and unobserved heterogeneity can be adequately controlled for. Unobserved heterogeneity causes numerous problems in empirical work, not least of which is the possibility of making erroneous inferences on the effects of measured variables. Secondly, the chances of a particular crosssection being in some sense atypical are reduced (see Mátyás and Sevestre, 1996, on the benefits of panel data in general)

The following section outlines the theory underlying why certain factors are considered important in the structure-conduct-performance analysis. Section 3 describes the data set more fully, followed by the estimation procedure in Section 4. The results are discussed in Section 5 and Section 6 concludes. 


\section{Structure-Conduct-Performance and Profitability}

One theoretical approach to analysing the financial performance of firms is that provided by the structure-conduct-performance paradigm, which was developed in the industrial organisation framework. This approach (in its simplest form) suggests that market structure influences market conduct, which in turn has an impact on the performance of the organisation. Those features of market structure that are expected to have the most influence over market conduct are seller and buyer concentration, product differentiation and barriers to entry (Capon, 1996). ${ }^{1}$ Although this framework has been established for the firm, it can just as easily be applied to tax entities. This is because the concept of the firm is flexible enough to allow tax entities to be treated as 'firms' for the purposes of this analysis, in that they have the potential to represent the financial data relating to a specific activity within a well-defined industry. The nature of the tax system could introduce into the analysis entities that are used for tax planning purposes, although the method used to calculate the price-cost margin and the estimating technique should limit the number of such entities entering into the analysis (see Section 3).

The homogenous product oligopoly model set out in Cowling and Waterson (1976) is the base for the empirical work in this paper. Following Machin and Van Reenen (1993) profitability - the price cost margin in this case—of entity $i$ is given by

$$
P C M_{i}=\frac{M S_{i}+\phi_{i}\left(1-M S_{i}\right)}{\varepsilon}
$$

where $M S_{i}$ is the market share of entity $i, \phi_{i}$ is a conjectural variation elasticity (the rival firm(s) output changes expected if firm $i$ alters output) and $\varepsilon$ is the industry price elasticity of demand. As in Machin and Van Reenen (1993), $\phi_{i}$ is a time varying function of concentration, minimum efficient scale and capital intensity. ${ }^{2}$ Given that (1) is to be estimated for each 3-digit ANZSIC industry, it can be assumed that the industry price elasticity of demand is the same for all firms in a given industry, such that $\varepsilon$ becomes a

\footnotetext{
1 More recent developments in the analysis of firm performance have involved integrating industrial organisation and strategic choice, but these issues will not be covered in this paper.

2 Entity size is excluded because the only practical measure available (log of total assets) is highly correlated with market share.
} 
constant and therefore does not feature in the estimation procedure (Cowling and Waterson, 1976, p. 269).

The price cost margin is the most commonly used measure of profitability in empirical studies of firm performance and indicates the ability of firms to elevate price above marginal cost (Feeny and Rogers, 1999, Liebowitz, 1982). Following Domowitz, Hubbard and Petersen (1986a, 1986b) and Prince (1994), the price cost margin is defined as:

$$
P C M=\frac{\text { Sales }+\Delta \text { Inventories }- \text { Cost of sales }}{\text { Sales }+\Delta \text { Inventories }}
$$

Cost of sales includes the cost of materials and labour cost. Depending on the stage of the business cycle, the value of sales may differ considerably from the value of output because of changes in inventories (Prince, 1994). Consequently, this definition of the price cost margin includes changes in inventories (calculated as closing stock minus opening stock) as their exclusion can cause biases in price cost margins.

The simple static structure-conduct-performance view of firm performance implies a positive relationship between market share and profitability due to market power. Advocates of this hypothesis contend that those with greater market power are able to charge higher prices (and therefore achieve superior levels of profit) due to 'market share related product differentiation' (Gale and Branch, 1982).

However, the structure-conduct-performance paradigm can be criticised in two important ways. The first is that firms are assumed to be homogenous within industries. All firms produce the same product using the same production methods. As mentioned in the introduction, firms rarely produce one product and operate in a single well-defined market. Once this unrealistic assumption is relaxed, the profitability of firms can differ due to differences in costs and product differentiation. Secondly, the paradigm fails to address the dynamic nature of firm performance.

Dynamic views of firm performance are better able to explain how differences in costs and products between firms exist. These views also offer an alternative explanation for a positive association between market share and profitability. Efficiency instead of market power provides the link, and stems from Brozen (1971) and Demsetz (1973). Their dynamic view of firm performance postulates that previous investments in innovations made by firms increase 
their sales and therefore increase their market share. Firm characteristics that lead to lower cost techniques - and therefore efficiency in production - allow the organisation to expand at the expense of its rivals. Once the firm garners enough of the market, the ability to maintain these efficiency advantages may be reinforced by factors such as economies of scale. This view therefore further differs form the traditional structure-conduct-performance view by assuming that industries can be out of long run equilibrium.

The debate between efficiency and market power and their role in determining profitability has important policy implications. If the market power view is perceived to be "correct", authorities may wish to intervene to limit the power of such firms through regulatory controls. However, such intervention would be very damaging to the economy if firms have large market shares simply because of superior efficiency.

Advocates of the hypothesis that as market share (and therefore market power) increases and competitive pressures are weakened, suggest that profitability is lower because the incentive to minimise costs is no longer as important. The limited amount of Australian empirical work on this issue either finds no significant relationship between profitability and market share (McDonald, 1999) or some evidence of a U-shaped relationship (Feeny, 2000; Feeny and Rogers, 1999). On the basis of the possible U-shaped relationship, market share and the square of market share are included, where market share is defined as the ratio of entity income to the 4-digit ANZSIC industry income to which the entity has been assigned. ${ }^{3}$

Concentration is hypothesised to facilitate collusion between firms and thereby increase profitability (Bain, 1956). It is also included as a proxy for the (possible) superior efficiency of larger firms (Levy, 1987), and is calculated in this paper as the sum of the market shares of the four largest entities in each 4-digit ANZSIC industry (also known as the four-firm concentration ratio). ${ }^{4}$ Early Australian studies that examine the relationship between profit and seller concentration do not reveal any significant association (Dixon et al, 1987 and Round, 1976, 1980a, 1980b for manufacturing; Tucker, 1977 for non-manufacturing). However, some recent studies have yielded more promising results. Although they adopt different approaches, both Feeny and Rogers (1999) and McDonald (1999) find the expected positive relationship between industry concentration and firm profit margins.

\footnotetext{
${ }^{3}$ 4-digit ANZSIC industry income is calculated as the sum of the income of all tax entities that are assigned that industry.
} 
There is a range of definitions of barriers to entry (see for example Demsetz, 1982) and all relate to the industry characteristics that place new entrants at a disadvantage relative to the established entrants in an industry. Barriers to entry are an important part of any industrial organisation framework. They imply that new firms are unable to easily enter the market to compete away supernormal profits that may have arisen because of concentration or market share (Hay and Morris, 1991). However, the relationship between barriers to entry and profit is difficult to capture in empirical estimation, as there is a wide variety of possible barriers. Additionally, the barrier is typically unobserved, that is, the size of the barrier is related to the expectation a potential entrant has about the post-entry equilibrium in the market (Geroski, 1991). Absolute cost advantages, product differentiation and scale economies are typically used in empirical estimation because they are relatively easy to measure (Hay and Morris, 1991).

Given the nature of the data to be used for this paper, a measure of scale economies is included, proxied by the minimum efficient scale (MES), one of the most common methods for measuring this variable. The minimum efficient scale is the size of firm at which long run average costs are at a minimum; if an industry has a very large minimum efficient scale, this may discourage potential firms from entering that market, thereby enabling the incumbent firm to realise greater profits. Following Comanor and Wilson (1967), minimum efficient scale is calculated as the average assets of the largest entities that account for 50 per cent of the industry. This measure is justified on the grounds that large firms should be able to take advantage of scale economies, as well as being insensitive to small firms that may be operating at a suboptimal scale.

Studies that use the price cost margin as the dependent variable commonly include capital intensity as an explanatory variable (Domowitz, Hubbard and Petersen 1986a, 1986b and Prince, 1994). There are two main reasons for this. The pragmatic reason is that the price cost margin is calculated without taking into account the cost of capital in production, and the capital intensity measure is included to capture this effect. ${ }^{5}$ The theoretical reason is that it can also proxy barriers to entry. A high capital intensity may reflect the existence of large

\footnotetext{
${ }^{4}$ Preliminary analysis also found this ratio was highly correlated with the Herfindahl measure of concentration.

5 Such an approach can be criticised for assuming that the rate of depreciation and barrier to entry effect of increments in the ratio is the same across all industries (Scherer and Ross, 1990). However, this is not an issue of substance for this paper, as the analysis is carried out at a 3-digit ANZSIC level of aggregation.
} 
sunk costs that act as a barrier to entry into the industry and so give rise to monopoly profits (McDonald, 1999). A positive association is therefore expected between entity profitability and capital intensity. Capital intensity is measured as the ratio of entity total assets to total income.

\section{The Australian Tax Office Tax Return Database}

This paper uses annual data from the Australian Tax Office tax return database for the 6-year period 1991/92 to 1996/97. Each year approximately 500,000 tax entities return data on their sales, costs, expenses and other financial activities. The size of the sample, the range of responses, and the panel nature of the dataset make this information ideal for the purposes of this study. Although there has been work done in Australia on the determinants of profitability, the limited availability of this particular dataset means that very little empirical research has been undertaken using this source. ${ }^{6}$

Many previous studies of the determinants of profitability have focused on the manufacturing sector. This is particularly true in Australia (see Feeny, 2000, for a review of the Australian literature). Using tax return data, analysis can be extended to industries throughout all sectors of the economy. On the tax return form, each tax entity is asked to allocate itself an ANZSIC code based upon the entity's activities that yield the highest amount of revenue. ${ }^{7}$ Therefore the large size of the database allows analysis to be carried out separately for individual industries, defined at a 3-digit ANZSIC level of aggregation.

A balanced panel of 28,951 tax entities is constructed, yielding a total of 173,706 observations for the six years of data. To be included in the panel, entities must have reported the financial information necessary to construct the price-cost margin and explanatory variables for each year of data $^{8}$. The final panel accounts for over 17 per cent of the total operating income of industries in Australia in 1997 (ABS, 1998).

A potential problem arising from using entities is that a tax entity could be a firm or a specific part of a firm, and there is no official limit on the number of tax entities a firm is able to have.

\footnotetext{
6 These data are confidential and remote access was authorised only to Melbourne Institute researchers under the specific research project agreement.

7 Before 1995-96, industry classification was based upon an internal Australian Tax Office categorisation.

8 Additionally, the use of a balanced panel means tax entities that have ceased operations are excluded, which may possibly introduce self-selection bias into the estimation.
} 
At best, a tax entity may be used to report a specific activity of a firm within a well-defined industry. At worst, a tax entity could be used for tax planning purposes and not represent any particular activity of a firm, thereby yielding no meaningful information as to what makes some firms more profitable than others.

This problem is ameliorated in two ways. Firstly, the profitability measure used here-the price-cost margin - is a much 'cleaner' measure than a definition based on income minus expenses. This is because income and expenses are more likely to be used as a method of reducing the company tax burden, rather than reflecting the income and expenses underlying the production process. In contrast, there are fewer opportunities for businesses to misrepresent their sales, inventories and cost of sales, which are required to calculate the profitability measure. As a result, there is a good chance that companies that are used for tax holding purposes will be removed from the data because they are unable to provide information on sales and cost of sales. Secondly, if any 'undesirables' are missed in this first round, they are accounted for through the adopted estimation technique. The WansbeekBekker dynamic panel estimator is utilised to analyse this tax return information, and one of its strengths is that it removes any unobserved heterogeniety, leaving only estimates of the 'true' effect of market structure on profitability.

\subsection{Summary Statistics}

Table 1 below reports some 1997 summary statistics for the tax entities included in the regression analysis. The summary statistics vary widely across the sample. For example, the average market share across the entire sample is 0.3 per cent of the industry total. However, there are tax entities that control a large part of their own market, with one entity accounting for nearly 90 per cent of the total. The capital intensity measure shows similar results. The average size of total assets is 57 per cent of total income, but there are some entities that have either very few assets, or their assets are more than 6 times that of their income.

Summary statistics by three-digit ANZSIC industry for the price cost margin and concentration are provided in Appendix Table A1. There is considerable variation in profitability and the market structure variables. Motor vehicle retailers (531) apparently have the smallest margins, averaging only 17.2 per cent, whereas dairy cattle farmers (013) enjoy price cost margins of nearly 90 per cent. Market concentration estimates also vary widely across industries. Exhibiting very low levels are veterinary services (864), which have an 
average 4-firm concentration ratio of 7.8 per cent, compared to nearly 80 per cent for department stores (521).

Table 1: Summary Statistics for the Regression Sample

\begin{tabular}{lccccc}
\hline Variable (1997) & Entities & Mean & SD & Min & Max \\
\hline Price Cost Margin (\%) & 28,951 & 43.41 & 22.19 & -20.20 & 99.99 \\
Capital Intensity (\%) & 28,951 & 56.90 & 58.57 & 0.00 & 611.86 \\
Market Share (\%) & 28,951 & 0.30 & 2.03 & 0.00 & 87.74 \\
Concentration (\%) & 28,951 & 29.04 & 19.13 & 0.64 & 99.86 \\
Log Minimum Efficient Scale & 28,951 & 16.98 & 2.16 & 12.07 & 24.19 \\
\hline
\end{tabular}

Note: The minimum values for capital intensity and market share are very small but are not zero. Entities with the lowest $1 \%$ of price-cost margin values were excluded from the regression analysis as where entities with the highest $1 \%$ of capital intensity values. This was a simple case of not wanting excessive outliers to bias the subsequent results and conclusions.

\section{Estimating Profitability in the Structure-Conduct-Performance Framework}

To move from Equation (1) to an equation that can be estimated, $\phi$ is specified as a function of the entity's contemporaneous characteristics $x_{i t}^{\prime}$ with unknown weights $\beta$. The vector $x_{i t}$ includes concentration, minimum efficient scale and capital intensity. A criticism of this basic specification is that the results may be driven by unobserved firm level heterogeneity (Machin and Van Reenen, 1993, Martin, 1993, Mueller and Raunig, 1999). However, use of this data set allows us to condition on such unobserved heterogeneity (Mátyás and Sevestre, 1996), which is labelled $\alpha_{i}$. In addition, this paper follows McDonald (1999), in postulating that there will be a significant degree of habit persistence in entities' profit margins. That is, it is expected that current profit margins will be heavily influenced by past realisations of such. Econometrically, this necessitates the additional inclusion of a lagged dependent variable (with unknown weight $\delta$ ) into the basic specification. Thus the estimated equation is

$$
y_{i t}=\alpha_{i}+\delta y_{i t-1}+\underline{x}_{i t}^{\prime} \underline{\beta}+u_{i t},
$$

where $u_{i t}$ are the usual white noise disturbance terms. ${ }^{9}$

The usual method of estimating equation (2), that is, when there is no lagged dependent variable, is biased and inconsistent as $N \rightarrow \infty$ and finite $T$ (Nickell, 1981, Sevestre and

\footnotetext{
9 Whether to treat the individual effects as "fixed" or "random", (see, for example, Mundlak, 1978a, b and Hsiao, 1985, 1986) is not an issue for the estimation procedure employed in this paper, as an unspecified transformation of the data is employed, such that the individual effects are removed. Indeed, the $\alpha_{i}$ of equation (2) are essentially 'nuisance' parameters.
} 
Trognon, 1985, and Nerlove, 1967, 1971). The dataset employed in this paper is of these dimensions, with 'small' $T$ and 'large' $N$. In the random effects setting this bias arises from a correlation between the lagged dependent variable and the individual effect, and in the fixed effects setting, there is the usual bias resulting from a lagged dependent variable and a short time-series (as is typical in panel datasets). However, many consistent estimators have been proposed (see Harris and Mátyás, 1996, for a useful review). Generally these take the form of Instrumental Variable estimators or, more generally, Generalised Method of Moments estimators. The approach taken in this paper follows that of Harris and Mátyás (2000), which in turn extends that of Wansbeek and Bekker (1996), as this estimation procedures has a robust performance (Harris and Mátyás, 1996, and Harris et al, 1996).

The usual way to estimate this model is to apply the Instrumental Variable/ Generalised Method of Moments approach (see, for example, Sevestre and Trognon, 1996). The original Wansbeek-Bekker estimator (which assumes that $\beta=0$ ) extends the set of instruments proposed by Anderson and Hsiao (1982), for example, by including lags and leads of the dependent variable (and linear combinations of these). That is, by defining the variable $y$ from $t=1$ to $t=T$, this estimator considers linear functions of $y_{+}$as instruments, where $y_{+}$is the stacked vector of observations defined from $t=0$ to $t=T$ for each observation. The linear functions are defined by the $(T+1) \times T$ matrix $A_{i}$, which yields $A^{\prime} y_{+}$as the full set of instruments (where $A=I_{N} \otimes A_{i}$ ). Restrictions are imposed on $A$ such that the individual effects are eliminated and consistency of the estimator ensured (Wansbeek and Bekker, 1996). ${ }^{10}$

With exogenous variables in the model, two types of such IV estimators can be derived depending on whether the instrument set is extended to similarly include transformations of the exogenous variables, such that

$$
Z=\left(A^{\prime} y_{+}, X\right) \quad \text { or } \quad Z_{+}=\left(A^{\prime} y_{+}, A^{\prime} X_{+}, X\right)
$$

To estimate model (2) using instrumental variables the variance-covariance matrix of the vector $Z^{\prime} u$ or $Z_{+}^{\prime} u$ is required (Bowden and Turkington, 1984). However, this matrix is quite complex due to the fact that $E\left(y_{+}^{\prime} u\right) \neq 0$. Harris and Mátyás (2000) propose an approximation

\footnotetext{
${ }^{10}$ This structure of $A$ not only eliminates the individual effects, but also means that the effects of any time invariant variables cannot be identified.
} 
of this true covariance matrix as $\sigma_{u}^{2}\left(Z^{\prime} Z\right)$ or $\sigma_{u}^{2}\left(Z_{+}^{\prime} Z_{+}\right)$, which effectively means that the cross correlation components of this (these) matrix (matrices) are not taken into account. Accordingly, the approximation of these estimators' semi-asymptotic covariance matrices are respectively, $\sigma_{u}^{2}\left(\tilde{X}^{\prime} Z\left(Z^{\prime} Z\right)^{-1} Z^{\prime} \tilde{X}\right)^{-1}$ and $\sigma_{u}^{2}\left(\tilde{X}^{\prime} Z_{+}\left(Z_{+}^{\prime} Z_{+}\right)^{-1} Z_{+}^{\prime} \tilde{X}\right)^{-1}$, both of which are functions of $A$. Thus the optimal choice of $A$ is that which minimises the trace of this (these) covariance matrix (matrices). ${ }^{11}$ Once $A$ has been found using any constrained optimisation routine, $Z$ and $Z_{+}$are known and the estimators become simple applications of the instrumental variables technique (Bowden and Turkington, 1984).

In addition to the endogeniety of the lagged dependent variable, the application is further complicated by the fact that both capital intensity and market share are also likely to be endogenous. This endogeniety arises from fact that entity-level variables are likely to be correlated with unobserved firm specific effects. This again justifies use of the WansbeekBekker estimator, as, through the transformation matrix $A$, it will reduce this correlation by elimination of any time-invariant heterogeneity. The approach followed in this paper was to use the expanded instrument set $Z_{+}$variant, but to use only the strictly exogenous elements of $X_{+}$(concentration and minimum efficient scale) and to instrument capital intensity and market share by two period lags of themselves.

\section{Results}

Regressions were run on a common set of variables for each of 91 three-digit ANZSIC industries that have more than 25 observations ( 58 per cent of all industries available). For ease of exposition, only the results for each of the significant coefficients are presented in Tables 2 through $6 .^{12}$ The full set of significant results are presented in Appendix Table A2. The first column of each table provides the coefficients found on each explanatory variable from the empirical analysis. Where there are a large number of different coefficients, then a range of coefficient values is provided. The second column of each table relates these values to the 3 digit ANZSIC industry codes for which they were significant. The industries associated with each code are provided in Appendix Table A1. As the model is linear the coefficients are interpreted as marginal effects.

\footnotetext{
${ }^{11}$ It is also possible to minimise the determinant but the resulting estimator is virtually identical (Harris and Mátyás, 2000).

${ }^{12}$ At the 5 per cent level.
} 


\subsection{Lagged price cost margin}

The coefficient on the lagged entity price cost margin is positive and significant for 40 per cent of industries and negative and significant for just one industry, Clubs in hospitality (574). Due to the number of industries that have significant coefficients on the lagged pricecost margin, the results are presented in bands in Table 2. Most of the coefficients are grouped between 0.60 and 0.89 , indicating that a 1 per cent increase in the price-cost margin last year will result in a $0.60-0.89$ per cent increase in the price-cost margin this year. The size of these coefficients implies that the return to equilibrium is monotonic $(\hat{\delta}<1)$ but "slow" $(\hat{\delta} \rightarrow 1)$. Several industries had at least a one-for-one relationship with price-costmargins last year. If the value of the coefficient exceeds one (or is less than minus one), it implies that profit margins never return to equilibrium. However, this is unlikely to be sustained in the long run, as in practice entities do not exhibit exponential profit growth. In general, there does not seem to be any particular trend of consistent levels of habit persistence across industries.

For more than half the industries in the sample a positive and significant coefficient on the lagged price cost margin was not found. One possible explanation for this finding is the movement of funds between different entities of a firm to minimise the tax bill. Another possibility is that these industries may be very competitive. In the absence of barriers to entry, high profits may lead to an increase in the number of firms (entities) into the industry and the resultant increase in competition will cause profits to fall. Under changing market conditions, profits in the previous year may not be a good indication of profits in the current year. If this were the case, insignificance of the lagged price cost margin and barriers to entry should go hand in hand. However, this is true of only 56 per cent of the industries, providing only limited support for this theory.

\section{Table 2: Coefficients on Lagged Price Cost Margin}

\begin{tabular}{ll}
\hline Coefficient & 3-digit ANZSIC code \\
\hline-1.34 & 574 \\
0.49 & 294 \\
$0.50-0.59$ & $217,241,451$ \\
$0.60-0.69$ & $218,276,283,453,531,573,862,912,951$ \\
$0.70-0.79$ & $273,479,931$ \\
$0.80-0.89$ & $255,263,275,462,512,524,526,783$ \\
$0.90-0.99$ & 281,525 \\
$1.00-1.09$ & $13,261,286,571$ \\
$1.10 \&$ above & $12,141,521,786,863$ \\
\hline
\end{tabular}




\subsection{Capital intensity}

Table 3 shows that capital intensity has a significant positive effect on the price cost margin for only 12 per cent of industries. The observation that very few industries are positive and significant should not necessarily be taken as an indication that capital intensity is an ineffective barrier to entry for the majority of tax entities. The minimum efficient scale measure (discussed below) is perhaps a better indicator of capital barriers to entry, as the primary function of capital intensity is to serve as a control variable for the price cost margin.

Table 3: Coefficients on Capital Intensity

\begin{tabular}{ll}
\hline Coefficient & 3-digit ANZSIC code \\
\hline 0.02 & Printing and services to printing (241) \\
0.05 & Building construction (411) \\
0.06 & Building completion services (424) \\
0.06 & Furniture, houseware \& appliance retailing (523) \\
0.06 & Technical services (782) \\
0.08 & Other crop growing (16) \\
0.08 & Site preparation services (421) \\
0.09 & Machinery \& equipment wholesaling (461) \\
0.10 & Basic chemical manufacturing (253) \\
0.11 & Dairy product manufacturing (212) \\
0.16 & Food, drink \& tobacco wholesaling (471) \\
\hline
\end{tabular}

\subsection{Market share}

Previous analysis (Feeny, 2000) has indicated evidence of a U-shaped relationship between market share and profitability. That is, market share is significantly negative (a result also found by McDonald (1999) on a different data set), but the square of market share is significantly positive. As Bennenbroek and Harris (1995) point out, such a relationship is implied by U-shaped average variable costs. Using these results, it is possible to determine a "threshold" level of market share, above which profitability increases with market share and below which it decreases.

These implied threshold values are reported in Table 4. Only 18 per cent of industries have significant coefficients on the market share variables. All of the industries that have a threshold level above the average (13 per cent) are engaged in manufacturing, with the exception of computer services (783). For basic chemical manufacturing (253), nearly 40 per cent of the market is required to be captured by an entity before any profits can be made from sheer market dominance. In comparison, building completion services (424) and clubs hospitality (574), require very minimal market share before reaping the rewards in terms of 
higher profitability. Unfortunately, it does not appear possible to empirically test whether the positive association between market share and profitability in these industries is due to greater efficiency or greater market power.

Table 4: Market Share Threshold Levels

\begin{tabular}{ll}
\hline Coefficient & 3-digit ANZSIC code \\
\hline 0.016 & Clubs (hospitality) (574) \\
0.018 & Building completion services (424) \\
0.038 & Installation trade services (423) \\
0.044 & Dairy product manufacturing (212) \\
0.054 & Accommodation (571) \\
0.076 & Food, drink \& tobacco wholesaling (471) \\
0.076 & Motor vehicle retailing (531) \\
0.090 & Household good retailing (473) \\
0.092 & Electronic equipment manufacturing (284) \\
0.132 & Computer services (783) \\
0.230 & Ceramic product manufacturing (262) \\
0.262 & Electrical equipment \& appliance manufacturing (285) \\
0.320 & Textile product manufacturing (222) \\
0.386 & Basic chemical manufacturing (253) \\
\hline
\end{tabular}

\subsection{Concentration}

Preliminary analysis that included a concentration variable indicated that concentration was negatively related to profitability for around one-third of industries, running counter to the theoretical arguments presented earlier. Previous empirical work (on cross section data) has suggested that the expected positive relationship between profitability and concentration does not appear in the 'line of business' regression with market share included (Gale and Branch, 1982; Ravenscraft, 1983; Shepherd, 1972). Feeny (2000) also found evidence of a negative relationship between concentration and profitability for some industries, a result that held regardless of whether or not market share was included.

\section{Table 5: Concentration Threshold Levels}

\begin{tabular}{ll}
\hline Coefficient & 3-digit ANZSIC code \\
\hline 0.304 & Cafes \& restaurants (573) \\
0.337 & Printing and services to printing (241) \\
0.404 & Other crop growing (16) \\
0.430 & Motor vehicle retailing (531) \\
0.452 & Electronic equipment manufacturing (284) \\
0.466 & Machinery \& equipment wholesaling (461) \\
0.536 & Dairy product manufacturing (212) \\
0.680 & Building completion services (424) \\
0.719 & Photographic \& scientific equipment manufacturing (283) \\
0.719 & Supermarket \& grocery stores (511) \\
\hline
\end{tabular}


Collusion between entities is more likely to occur when seller concentration is high. This implies that the concentration-profit link is discontinuous, with the expected relationship occurring above a threshold level. Studies of US data have found a critical level of four firm concentration to be between 46 and 60 per cent, and that there is little evidence that increases in seller concentration to levels below 50 have any effect on profitability (Scherer and Ross, 1990). To investigate this possibility, a 'square of concentration' variable is included in the estimation to identify concentration threshold levels. Table 5 shows that only 11 of the 91 industries have what could be classified as a U-shaped relationship between concentration and profitability, covering a range of industries. The critical bounds appear to be wider than that found for the US, ranging from around 30 per cent for cafes and restaurants (573) to around 70 per cent for photographic and scientific equipment manufacturing (283) and supermarket and grocery stores (511).

\subsection{Minimum efficient scale}

Minimum efficient scale coefficients are presented in Table 6 and show that this variable has a positive and significant effect on the price cost margin for 38 per cent of industries. The magnitude of the coefficients indicates that a relatively small amount of capital is required to ensure a positive relationship with profitability. These estimates are in direct contrast to Feeny (2000), where it was found that only 19 per cent of industries had a significant coefficient on minimum efficient scale, and, of those, most were negative. However, less than 30 per cent of industries that exhibit a positive association between barriers to entry and profitability also have a positive and significant coefficient on the lagged price cost margin. This might indicate that barriers to entry are not effective at preventing new firms from entering an industry and bidding down profits.

\section{Table 6: Coefficients on the Minimum Efficient Scale}

\begin{tabular}{ll}
\hline Coefficient & 3-digit ANZSIC code \\
\hline-0.03 & 12 \\
0.01 & $222,241,276,284,294,451,453,471,511$ \\
0.02 & $218,226,253,256,282,283,285,421,422,473,523,862$ \\
0.03 & $254,292,423,461$ \\
0.04 & $212,412,472,611,785$ \\
0.05 & 13,424 \\
0.07 & 574 \\
0.08 & 425 \\
\hline
\end{tabular}




\subsection{Summary}

Appendix Table A2 shows that the structure-conduct-performance framework has a significant relationship with the price-cost margin for certain industries, and is indicated by the significant coefficients on the explanatory variables. These include dairy product manufacturing, printing and services to printing, basic chemical manufacturing, photographic and scientific equipment manufacturing, electronic equipment manufacturing, site preparation services, installation trade services, building completion services, machinery and equipment wholesaling, food, drink and tobacco wholesaling, motor vehicle retailing and clubs (hospitality). In contrast, the structure-conduct-performance framework does a poor job in explaining the price-cost margin in the service industries, particularly finance, health, community, cultural, recreational, personal and other. This could indicate that the firms in these industries are too heterogenous for the structure-conduct-performance framework to be of much use, justifying the decision to estimate the regression on an industry-by-industry basis.

\section{Conclusion}

This paper indicates that market structure variables are important determinants of the price cost margin for just over half of the industries analysed. Although all of the independent variables were significant for only 2 of the 91 industries, this is not a particular cause for concern as it was indeed these very differences that prompted an estimation technique that used a 3-digit ANZSIC classification. Indeed, the difference in parameter estimates across industries questions the validity of results of previous studies that restricted them to be equal and explained industry differences by "shift" (or industry dummy) variables.

Scale economies appear to be important for most entities. The observation that few of these entities also have a positive and significant coefficient on the lagged price cost margin however, indicates that barriers to entry are not effective at preventing new firms from entering industries and bidding down profits. Making a profit in the previous year also boosts the chances of making one in the current year for a large number of industries. Capital intensity, market share and concentration on the other hand, affected the profitability of only a select group of industries.

A policy debate that has arisen in the structure-conduct-performance literature is the extent to which a positive profits-concentration or profits-market share relationship reflects efficient 
production that requires large-scale operations, or collusion among firms within the industry. In effect, concentration measures market power at the industry level, whereas market share measures market power for an individual firm. Preliminary estimates suggested that both concentration and market share should be included as quadratics, possibly because the average cost curve for individual firms and particular industries are U-shaped. Inclusion of the quadratic term for concentration indicated that-for 11 industries at least-there is a minimum level of concentration required before there is any positive association between concentration and profits. Similarly, only 16 industries experience market share levels above which profitability increases with market share. Although the nature of the data limits the ability to disentangle efficiency effects from collusion, the results suggest that policymakers would need to examine these industries on their merits to determine whether or not concentration—or a large market share—is a good thing.

Firm level heterogeneity has been found to be important in a range of structure-conductperformance studies (Machin and Van Reenen, 1993, Martin, 1993, Mueller and Raunig, 1999, Ravenscraft, 1983, Shepherd, 1972). The availability of panel data on Australian firms allowed for the control of unobserved individual entity heterogeneity. As a result, it was found that the effectiveness of the structure-conduct-performance framework is a useful tool in helping explain price-cost margins for particular industries, but in other cases the entities are too heterogeneous, thus offsetting any information that may be provided by the structureconduct-performance framework. It is also evident that the strongest driving forces of pricecost margins are previous realisations of the price-cost margin and the minimum efficient scale. 


\section{Appendix: Summary Statistics and Estimation Results}

Appendix Table A1: Summary Statistics by 3-Digit ANZSIC

\begin{tabular}{|c|c|c|c|}
\hline 3-Digit ANZSIC Industry & Entities & $\begin{array}{c}\text { Price Cost Margin } \\
\text { (average) }\end{array}$ & Concentration \\
\hline \multicolumn{4}{|l|}{ Agriculture } \\
\hline Horticulture \& Fruit Growing (011) & 158 & 61.3 & 23.8 \\
\hline Grain, Sheep \& Beef Cattle Farming (012) & 305 & 81.8 & 25.5 \\
\hline Dairy Cattle Farming (013) & 63 & 88.2 & 23.5 \\
\hline Other Crop Growing (016) & 25 & 64.6 & 37.2 \\
\hline Services to Agriculture (021) & 139 & 36.1 & 27.2 \\
\hline \multicolumn{4}{|l|}{ Mining } \\
\hline Construction Material Mining (141) & 45 & 60.2 & 44.8 \\
\hline \multicolumn{4}{|l|}{ Manufacturing } \\
\hline Meat \& Meat Product Manufacturing (211) & 78 & 34.5 & 46.5 \\
\hline Dairy Product Manufacturing (212) & 41 & 35.9 & 53.1 \\
\hline Other Food Manufacturing (217) & 179 & 42.5 & 48.3 \\
\hline Beverage \& Malt Manufacturing (218) & 68 & 48.4 & 56.1 \\
\hline Textile Fibre, Yarn \& Woven Fabric Manufacturing (221) & 38 & 46.9 & 47.7 \\
\hline Textile Product Manufacturing (222) & 186 & 48.1 & 34.5 \\
\hline Clothing Manufacturing (224) & 324 & 47.4 & 19.1 \\
\hline Footwear Manufacturing (225) & 49 & 46.5 & 34.0 \\
\hline Leather \& Leather Product Manufacturing (226) & 53 & 43.3 & 42.7 \\
\hline Log Sawmilling \& Timber Dressing (231) & 119 & 48.1 & 38.9 \\
\hline Other Wood Product Manufacturing (232) & 212 & 48.6 & 35.3 \\
\hline Paper \& Paper Product Manufacturing (233) & 62 & 44.8 & 59.3 \\
\hline Printing \& Services to Printing (241) & 732 & 58.4 & 18.8 \\
\hline Publishing (242) & 88 & 61.3 & 37.2 \\
\hline Basic Chemical Manufacturing (253) & 68 & 49.7 & 49.5 \\
\hline Other Chemical Product Manufacturing (254) & 229 & 47.8 & 46.3 \\
\hline Rubber Product Manufacturing (255) & 84 & 42.8 & 41.8 \\
\hline Plastic Product Manufacturing (256) & 272 & 50.4 & 31.1 \\
\hline Glass \& Glass Product Manufacturing (261) & 86 & 53.4 & 59.7 \\
\hline Ceramic Product Manufacturing (262) & 57 & 54.8 & 58.3 \\
\hline Cement, Lime, Plaster \& Concrete Product Manufacturing (263) & 144 & 48.4 & 57.6 \\
\hline Non-Metallic Mineral Product Manufacturing n.e.c. (264) & 30 & 48.0 & 61.5 \\
\hline Iron \& Steel Manufacturing (271) & 142 & 48.5 & 57.5 \\
\hline Non-Ferrous Basic Metal Product Manufacturing (273) & 40 & 47.0 & 59.7 \\
\hline Structural Metal Product Manufacturing (274) & 199 & 43.5 & 37.9 \\
\hline Sheet Metal Product Manufacturing (275) & 179 & 51.6 & 26.9 \\
\hline Fabricated Metal Product Manufacturing (276) & 463 & 53.6 & 37.1 \\
\hline Motor Vehicle \& Part Manufacturing (281) & 377 & 40.1 & 40.0 \\
\hline Other Transport Equipment Manufacturing (282) & 92 & 44.7 & 51.0 \\
\hline Photographic \& Scientific Equipment Manufacturing (283) & 178 & 57.5 & 35.7 \\
\hline Electronic Equipment Manufacturing (284) & 119 & 47.0 & 41.7 \\
\hline Electrical Equipment \& Appliance Manufacturing (285) & 323 & 45.8 & 34.0 \\
\hline Industrial Machinery \& Equipment Manufacturing (286) & 497 & 46.8 & 34.9 \\
\hline Prefabricated Building Manufacturing (291) & 95 & 47.7 & 34.9 \\
\hline Furniture Manufacturing (292) & 507 & 48.0 & 16.3 \\
\hline Other Manufacturing (294) & 827 & 49.0 & 27.5 \\
\hline \multicolumn{4}{|l|}{ Construction } \\
\hline Building Construction (411) & 312 & 38.2 & 16.4 \\
\hline Non-Building Construction (412) & 101 & 44.0 & 34.0 \\
\hline Site Preparation Services (421) & 46 & 59.6 & 14.5 \\
\hline Building Structure Services (422) & 98 & 45.4 & 21.3 \\
\hline
\end{tabular}




\begin{tabular}{|c|c|c|c|}
\hline 3-Digit ANZSIC Industry & Entities & $\begin{array}{c}\text { Price Cost Margin } \\
\text { (average) }\end{array}$ & Concentration \\
\hline Installation Trade Services (423) & 1,101 & 50.9 & 17.0 \\
\hline Building Completion Services (424) & 402 & 51.6 & 16.4 \\
\hline Other Construction Services (425) & 158 & 47.7 & 30.2 \\
\hline \multicolumn{4}{|l|}{ Wholesale Trade } \\
\hline Farm Produce Wholesaling (451) & 261 & 32.7 & 24.9 \\
\hline Mineral, Metal \& Chemical Wholesaling (452) & 304 & 30.1 & 44.6 \\
\hline Builders supplies Wholesaling (453) & 569 & 33.6 & 25.7 \\
\hline Machinery \& Equipment Wholesaling (461) & 1,076 & 34.9 & 27.4 \\
\hline Motor Vehicle Wholesaling (462) & 611 & 31.9 & 25.7 \\
\hline Food, Drink \& Tobacco Wholesaling (471) & 507 & 22.9 & 37.0 \\
\hline Textile, Clothing \& Footwear Wholesaling (472) & 291 & 35.6 & 30.0 \\
\hline Household Good Wholesaling (473) & 208 & 35.5 & 29.6 \\
\hline Other Wholesaling (479) & 1,346 & 33.5 & 33.3 \\
\hline \multicolumn{4}{|l|}{ Retail Trade } \\
\hline Supermarket \& Grocery Stores (511) & 265 & 20.5 & 69.3 \\
\hline Specialised Food Retailing (512) & 951 & 36.9 & 28.5 \\
\hline Department Stores (521) & 85 & 24.8 & 79.4 \\
\hline Clothing \& Soft Good Retailing (522) & 783 & 39.8 & 31.0 \\
\hline Furniture, Houseware, \& Appliance Retailing (523) & 1,265 & 32.4 & 30.2 \\
\hline Recreational Good Retailing (524) & 903 & 32.1 & 19.7 \\
\hline Other Personal \& Household Good Retailing (525) & 2,141 & 38.5 & 33.3 \\
\hline Household Equipment Repair Services (526) & 191 & 62.7 & 26.6 \\
\hline Motor Vehicle Retailing (531) & 709 & 17.2 & 11.9 \\
\hline Motor Vehicle Services (532) & 2,364 & 39.8 & 12.9 \\
\hline \multicolumn{4}{|l|}{ Accommodation, Cafes \& Restaurants } \\
\hline Accommodation (571) & 228 & 66.0 & 16.1 \\
\hline Pubs, Taverns \& Bars (572) & 404 & 48.4 & 15.0 \\
\hline Cafes \& Restaurants (573) & 607 & 59.2 & 29.3 \\
\hline Clubs (Hospitality) (574) & 175 & 56.1 & 10.2 \\
\hline \multicolumn{4}{|l|}{ Transport \& Storage } \\
\hline Road Freight Transport (611) & 38 & 55.9 & 33.0 \\
\hline Other Services to Transport (664) & 43 & 38.7 & 28.2 \\
\hline \multicolumn{4}{|l|}{ Finance \& Insurance } \\
\hline Financial Asset Investors (734) & 45 & 28.4 & 19.5 \\
\hline \multicolumn{4}{|l|}{ Property \& Business Services } \\
\hline Property Operators \& Developers (771) & 39 & 44.0 & 17.8 \\
\hline Machinery \& Equipment Hiring \& Leasing (774) & 39 & 60.2 & 32.1 \\
\hline Technical Services (782) & 466 & 53.3 & 20.5 \\
\hline Computer Services (783) & 172 & 45.6 & 23.7 \\
\hline Marketing \& Business Management Services (785) & 189 & 55.8 & 16.9 \\
\hline Other Business Services (786) & 213 & 54.2 & 36.4 \\
\hline \multicolumn{4}{|l|}{ Health \& Community Services } \\
\hline Medical \& Dental Services (862) & 36 & 71.9 & 8.5 \\
\hline Other Health Services (863) & 205 & 61.9 & 33.4 \\
\hline Veterinary Services $(864)$ & 46 & 68.1 & 7.8 \\
\hline \multicolumn{4}{|l|}{ Cultural \& Recreational Services } \\
\hline Film \& Video Services (911) & 65 & 63.5 & 38.6 \\
\hline Radio \& Television Services (912) & 33 & 65.1 & 35.1 \\
\hline Sport (931) & 147 & 60.7 & 19.1 \\
\hline Other Recreation Services (933) & 39 & 65.4 & 26.0 \\
\hline \multicolumn{4}{|l|}{ Personal \& Other Services } \\
\hline Personal \& Household Goods Hiring (951) & 76 & 63.4 & 22.3 \\
\hline Other Personal Services (952) & 524 & 70.1 & 27.5 \\
\hline Interest Groups (962) & 102 & 46.0 & 20.8 \\
\hline
\end{tabular}


Appendix Table A2: Estimation Results by 3-Digit ANZSIC (significant coefficients reported)

\begin{tabular}{|c|c|c|c|c|c|c|c|}
\hline & $\begin{array}{l}\text { Lagged } \\
\text { price-cost } \\
\text { margin }\end{array}$ & $\begin{array}{c}\text { Capital } \\
\text { intensity }\end{array}$ & $\begin{array}{c}\text { Market } \\
\text { share }\end{array}$ & $\begin{array}{c}\text { Market } \\
\text { share }^{2}\end{array}$ & Concentration & Concentration $^{2}$ & $\begin{array}{c}\text { Minimum } \\
\text { efficient } \\
\text { scale }\end{array}$ \\
\hline \multicolumn{8}{|l|}{ Agriculture } \\
\hline 11 & - & - & - & - & - & - & - \\
\hline 12 & 1.53 & - & - & - & - & - & -0.03 \\
\hline & $(6.12)$ & - & - & - & - & - & $(1.95)$ \\
\hline 13 & 1.05 & - & - & - & - & - & 0.05 \\
\hline & $(5.03)$ & - & - & - & - & - & (1.96) \\
\hline 16 & - & 0.08 & - & - & 3.33 & -4.12 & - \\
\hline & - & $(1.95)$ & - & - & $(3.34)$ & $(3.53)$ & - \\
\hline 21 & - & - & - & - & -0.49 & - & - \\
\hline & - & - & - & - & $(1.97)$ & - & - \\
\hline \multicolumn{8}{|l|}{ Mining } \\
\hline 141 & 1.15 & - & - & - & - & - & - \\
\hline & $(2.34)$ & - & - & - & - & - & - \\
\hline \multicolumn{8}{|l|}{ Manufacturing } \\
\hline 211 & - & - & - & - & - & - & - \\
\hline 212 & - & 0.11 & -10.50 & 119.13 & -1.92 & 1.79 & 0.04 \\
\hline & - & $(2.01)$ & $(2.44)$ & $(2.39)$ & $(2.71)$ & $(2.93)$ & $(3.02)$ \\
\hline 217 & 0.57 & - & - & - & - & - & - \\
\hline & $(2.09)$ & - & - & - & - & - & - \\
\hline 218 & 0.67 & - & - & - & - & - & 0.02 \\
\hline & (3.39) & - & - & - & - & - & $(2.00)$ \\
\hline 221 & - & - & - & -2.73 & - & - & - \\
\hline & - & - & - & $(2.49)$ & - & - & - \\
\hline 222 & - & - & -1.70 & 2.66 & - & - & 0.01 \\
\hline & - & - & $(2.20)$ & $(2.40)$ & - & - & $(2.49)$ \\
\hline 224 & - & - & - & - & - & - & - \\
\hline 225 & - & - & - & - & - & - & - \\
\hline 226 & - & - & -11.93 & - & - & - & 0.02 \\
\hline & - & - & $(2.06)$ & - & - & - & $(1.92)$ \\
\hline 231 & - & - & - & - & - & - & - \\
\hline 232 & - & - & - & - & - & - & - \\
\hline 233 & - & - & - & - & - & - & - \\
\hline 241 & 0.57 & 0.02 & - & - & 0.33 & -0.49 & 0.01 \\
\hline & $(4.81)$ & $(2.05)$ & - & - & $(2.25)$ & $(2.10)$ & $(3.25)$ \\
\hline 242 & - & - & - & - & - & - & - \\
\hline 253 & - & 0.10 & -2.70 & 3.50 & - & - & 0.02 \\
\hline & - & (2.71) & $(3.67)$ & $(3.73)$ & - & - & $(3.17)$ \\
\hline 254 & - & - & - & - & - & - & 0.03 \\
\hline & - & - & - & - & - & - & $(4.75)$ \\
\hline 255 & 0.84 & - & - & - & - & - & - \\
\hline & $(5.40)$ & - & - & - & - & - & - \\
\hline 256 & - & - & - & - & - & - & 0.02 \\
\hline & - & - & - & - & - & - & (3.18) \\
\hline 261 & 1.07 & - & - & - & - & - & - \\
\hline & $(2.53)$ & - & - & - & - & - & - \\
\hline 262 & - & - & -1.86 & 4.04 & - & - & - \\
\hline & - & - & $(1.97)$ & $(2.16)$ & - & - & - \\
\hline 263 & 0.80 & - & - & - & - & - & - \\
\hline & (4.63) & - & - & - & - & - & - \\
\hline
\end{tabular}




\begin{tabular}{|c|c|c|c|c|c|c|c|}
\hline & $\begin{array}{l}\text { Lagged } \\
\text { price-cost } \\
\text { margin }\end{array}$ & $\begin{array}{c}\text { Capital } \\
\text { intensity }\end{array}$ & $\begin{array}{c}\text { Market } \\
\text { share }\end{array}$ & $\begin{array}{l}\text { Market } \\
\text { share }^{2}\end{array}$ & Concentration & Concentration $^{2}$ & $\begin{array}{l}\text { Minimum } \\
\text { efficient } \\
\text { scale }\end{array}$ \\
\hline 264 & - & - & - & - & - & - & - \\
\hline 271 & - & - & - & - & - & - & - \\
\hline \multirow[t]{2}{*}{273} & 0.70 & - & - & - & 0.69 & - & - \\
\hline & $(3.57)$ & - & - & - & (1.99) & - & - \\
\hline 274 & - & - & - & - & - & - & - \\
\hline \multirow{2}{*}{275} & 0.89 & - & - & - & - & - & - \\
\hline & $(6.82)$ & - & - & - & - & - & - \\
\hline \multirow[t]{2}{*}{276} & 0.63 & - & - & - & - & - & 0.01 \\
\hline & (3.38) & - & - & - & - & - & $(2.26)$ \\
\hline \multirow[t]{2}{*}{281} & 0.92 & - & - & - & - & - & - \\
\hline & (3.33) & - & - & - & - & - & - \\
\hline \multirow[t]{2}{*}{282} & - & - & - & - & - & - & 0.02 \\
\hline & - & - & - & - & - & - & (3.47) \\
\hline \multirow[t]{2}{*}{283} & 0.68 & - & - & - & -0.46 & 0.32 & 0.02 \\
\hline & $(5.17)$ & - & - & - & $(2.30)$ & $(2.00)$ & $(2.59)$ \\
\hline \multirow[t]{2}{*}{284} & - & - & -14.58 & 79.50 & 1.59 & -1.76 & 0.01 \\
\hline & - & - & (3.99) & $(3.61)$ & $(5.37)$ & $(5.16)$ & $(2.65)$ \\
\hline \multirow[t]{2}{*}{285} & - & - & -1.41 & 2.69 & - & - & 0.02 \\
\hline & - & - & $(2.43)$ & $(2.35)$ & - & - & $(3.36)$ \\
\hline \multirow{2}{*}{286} & 1.05 & - & - & - & - & - & - \\
\hline & $(4.90)$ & - & - & - & - & - & - \\
\hline 291 & - & - & - & - & - & - & - \\
\hline \multirow{2}{*}{292} & - & - & - & - & - & - & 0.03 \\
\hline & - & - & - & - & - & - & (1.94) \\
\hline \multirow[t]{2}{*}{294} & 0.49 & - & -3.18 & - & - & - & 0.01 \\
\hline & $(5.99)$ & - & $(2.19)$ & - & - & - & $(5.61)$ \\
\hline \multicolumn{8}{|l|}{ Construction } \\
\hline \multirow[t]{2}{*}{411} & - & 0.05 & - & - & - & - & - \\
\hline & - & $(3.21)$ & - & - & - & - & - \\
\hline \multirow[t]{2}{*}{412} & - & - & - & - & - & - & 0.04 \\
\hline & - & - & - & - & - & - & $(2.49)$ \\
\hline \multirow[t]{2}{*}{421} & - & 0.08 & -36.11 & - & 2.50 & - & 0.02 \\
\hline & - & (3.61) & $(1.93)$ & - & $(1.95)$ & - & (1.99) \\
\hline \multirow[t]{2}{*}{422} & - & - & - & - & - & - & 0.02 \\
\hline & - & - & - & - & - & - & $(1.98)$ \\
\hline \multirow[t]{2}{*}{423} & - & - & -18.44 & 241.75 & -0.30 & - & 0.03 \\
\hline & - & - & $(2.25)$ & $(2.05)$ & (2.39) & - & $(2.81)$ \\
\hline \multirow[t]{2}{*}{424} & - & 0.06 & -28.00 & 789.85 & -1.70 & 1.25 & 0.05 \\
\hline & - & (3.29) & $(4.33)$ & $(3.16)$ & $(5.24)$ & $(4.49)$ & $(5.61)$ \\
\hline \multirow[t]{2}{*}{425} & - & - & - & - & - & - & 0.08 \\
\hline & - & - & - & - & - & - & $(1.93)$ \\
\hline Wholesale trade & & & & & & & \\
\hline 451 & 0.51 & - & - & - & - & - & 0.01 \\
\hline & $(1.95)$ & - & - & - & - & - & $(1.92)$ \\
\hline 452 & - & - & - & - & - & - & - \\
\hline 453 & 0.60 & - & - & 125.39 & - & - & 0.01 \\
\hline & $(3.08)$ & - & - & $(2.08)$ & - & - & $(2.18)$ \\
\hline 461 & - & 0.09 & - & - & -0.96 & 1.03 & 0.03 \\
\hline & - & $(3.22)$ & - & - & $(4.16)$ & $(3.70)$ & $(5.19)$ \\
\hline 462 & 0.89 & - & - & - & - & - & - \\
\hline & $(7.70)$ & - & - & - & - & - & - \\
\hline
\end{tabular}




\begin{tabular}{|c|c|c|c|c|c|c|c|}
\hline & $\begin{array}{l}\text { Lagged } \\
\text { price-cost } \\
\text { margin }\end{array}$ & $\begin{array}{c}\text { Capital } \\
\text { intensity }\end{array}$ & $\begin{array}{c}\text { Market } \\
\text { share }\end{array}$ & $\begin{array}{l}\text { Market } \\
\text { share }^{2}\end{array}$ & Concentration & Concentration $^{2}$ & $\begin{array}{l}\text { Minimum } \\
\text { efficient } \\
\text { scale }\end{array}$ \\
\hline 471 & - & 0.16 & -4.26 & 28.18 & - & - & 0.01 \\
\hline & - & $(3.70)$ & (3.41) & $(3.05)$ & - & - & $(4.24)$ \\
\hline 472 & - & - & - & - & - & - & 0.04 \\
\hline & - & - & - & - & - & - & $(3.02)$ \\
\hline 473 & - & - & -1.95 & 10.86 & - & - & 0.02 \\
\hline & - & - & $(1.91)$ & $(2.65)$ & - & - & $(2.65)$ \\
\hline 479 & 0.77 & - & - & - & - & - & - \\
\hline & $(2.96)$ & - & - & - & - & - & - \\
\hline \multirow[t]{19}{*}{ Retail trade } & - & & & & & & \\
\hline & - & - & - & - & -0.46 & 0.32 & 0.01 \\
\hline & - & - & - & - & $(2.26)$ & $(2.17)$ & $(2.38)$ \\
\hline & 0.83 & - & - & - & - & - & - \\
\hline & $(2.35)$ & - & - & - & - & - & - \\
\hline & 1.65 & - & - & - & - & - & - \\
\hline & $(2.40)$ & - & - & - & - & - & - \\
\hline & - & - & - & - & - & - & - \\
\hline & - & 0.06 & - & - & -0.39 & - & 0.02 \\
\hline & - & (2.74) & - & - & $(2.34)$ & - & $(5.70)$ \\
\hline & 0.84 & - & - & - & - & - & - \\
\hline & $(4.01)$ & - & - & - & - & - & - \\
\hline & 0.95 & - & - & - & - & - & - \\
\hline & $(3.14)$ & - & - & - & - & - & - \\
\hline & 0.87 & - & - & - & - & - & - \\
\hline & $(2.34)$ & - & - & - & - & - & - \\
\hline & 0.65 & - & -2.99 & 19.60 & 0.37 & -0.43 & - \\
\hline & $(2.69)$ & - & $(2.11)$ & $(2.13)$ & $(2.07)$ & $(2.08)$ & - \\
\hline & - & - & - & - & - & - & - \\
\hline \multicolumn{8}{|c|}{ Accommodation, cafes and restaurants } \\
\hline 571 & 1.03 & - & -3.10 & 28.45 & - & - & - \\
\hline & $(4.82)$ & - & $(2.21)$ & $(2.05)$ & - & - & - \\
\hline 572 & - & - & - & - & - & - & - \\
\hline 573 & 0.67 & - & - & - & 0.28 & -0.46 & - \\
\hline & (3.29) & - & - & - & $(3.55)$ & $(3.57)$ & - \\
\hline 574 & -1.34 & - & 64.96 & -2016.42 & - & - & 0.07 \\
\hline & $(3.26)$ & - & $(4.03)$ & $(3.49)$ & - & - & $(5.25)$ \\
\hline \multicolumn{8}{|c|}{ Transport and storage } \\
\hline 611 & - & - & - & - & - & - & 0.04 \\
\hline & - & - & - & - & - & - & $(2.14)$ \\
\hline 664 & - & - & - & - & - & - & - \\
\hline \multicolumn{8}{|c|}{ Finance and insurance } \\
\hline 734 & - & - & - & - & - & - & - \\
\hline \multicolumn{8}{|c|}{ Property and business services } \\
\hline 771 & - & - & - & - & - & - & - \\
\hline 774 & - & - & -23.49 & - & 1.34 & - & - \\
\hline & - & - & $(2.46)$ & - & $(1.92)$ & - & - \\
\hline 782 & - & 0.06 & - & - & - & -0.35 & - \\
\hline & - & $(2.72)$ & - & - & - & $(2.22)$ & - \\
\hline 783 & 0.82 & - & -3.19 & 12.04 & - & - & - \\
\hline & $(5.45)$ & - & $(2.08)$ & $(2.21)$ & - & - & - \\
\hline 785 & - & - & - & - & - & - & 0.04 \\
\hline & - & - & - & - & - & - & $(2.27)$ \\
\hline
\end{tabular}




\begin{tabular}{|c|c|c|c|c|c|c|c|}
\hline & $\begin{array}{l}\text { Lagged } \\
\text { price-cost } \\
\text { margin }\end{array}$ & $\begin{array}{c}\text { Capital } \\
\text { intensity }\end{array}$ & $\begin{array}{c}\text { Market } \\
\text { share }\end{array}$ & $\begin{array}{l}\text { Market } \\
\text { share }^{2}\end{array}$ & Concentration & Concentration $^{2}$ & $\begin{array}{c}\text { Minimum } \\
\text { efficient } \\
\text { scale }\end{array}$ \\
\hline 786 & 1.42 & - & - & - & - & - & - \\
\hline & $(5.67)$ & - & - & - & - & - & - \\
\hline \multicolumn{8}{|c|}{ Health and community services } \\
\hline 862 & 0.65 & - & - & - & - & - & 0.02 \\
\hline & $(3.94)$ & - & - & - & - & - & $(1.95)$ \\
\hline 863 & 1.25 & - & - & - & - & - & - \\
\hline & $(2.07)$ & - & - & - & - & - & - \\
\hline 864 & - & - & - & - & - & - & - \\
\hline \multicolumn{8}{|c|}{ Cultural and recreational services } \\
\hline 911 & - & - & - & - & - & - & - \\
\hline 912 & 0.67 & - & - & - & - & - & - \\
\hline & $(2.05)$ & - & - & - & - & - & - \\
\hline 931 & 0.72 & - & - & - & - & - & - \\
\hline & $(3.27)$ & - & - & - & - & - & - \\
\hline 933 & - & - & - & - & - & - & - \\
\hline \multicolumn{8}{|c|}{ Personal and other services } \\
\hline 951 & 0.68 & - & - & - & - & - & - \\
\hline & $(2.24)$ & - & - & - & - & - & - \\
\hline 952 & - & - & - & - & - & - & - \\
\hline 962 & - & - & - & - & - & - & - \\
\hline
\end{tabular}




\section{References}

Anderson, T.W. and Hsiao, C. (1982). "Formulation and Estimation of Dynamic Models Using Panel Data", Journal of Econometrics, Vol. 18, pp. 578-606.

Bain, J. S. (1956). Barriers to New Competition. Cambridge, Harvard University Press.

Bennenbroek, N. and Harris, R. I. D. (1995) "An Investigation of the Determinants of Profitability in New Zealand Manufacturing Industries in 1986-87", Applied Economics, 27(11), pp. 1093-1101

Bowden, R.J. and Turkington, D.A. (1984). Instrumental Variables, Cambridge University Press, Cambridge.

Brozen, Y. (1971), “Bain's Concentration and Rates of Return Revisited”, Journal of Law and Economics 14: 351-69

Comanor, W.S. and Wilson, T.S. (1967), “Advertising, Market Structure and Performance”, Review of Economics and Statistics, 49: 423-40.

Cowling, K. and Waterson, M. (1976). "Price-Cost Margins and Market Structure", Economica, 43, pp. 267-274.

Demsetz (1973), "Industry Structure, Market Rivalry, and Public Policy”, Journal of Law and Economics, 16:1-9.

Demsetz, H. (1982). “Barriers to Entry”, American Economic Review, 72(1), pp. 47-57.

Dixon, B. L., Garcia, P. and Anderson, M. (1987). "Usefulness of Pretests for Estimating Underlying Technologies Using Dual Profit Functions”, International Economic Review, 28(3), pp. 623-33.

Domowitz, I., Hubbard, R.G. and Petersen, B. C. (1986a). "The intertemporal stability of the concentration-margins relationship", Journal of Industrial Economics, 35(1), pp.13-34.

Domowitz, I., Hubbard, R.G. and Petersen, B. C. (1986b). "Business cycles and the relationship between concentration and price-cost margins", Rand Journal of Economics, 17(1), pp. 1-17. 
Feeny, S. (2000). "Determinants of Profitability: An Empirical Investigation Using Australian Tax Entities", Melbourne Institute of Applied Economic and Social Research Working Paper No. 01/00, University of Melbourne.

Feeny, S. and Rogers, M. (1999). "Market Share, Concentration and Diversification in Firm Profitability". Melbourne Institute of Applied Economic and Social Research Working Paper 20/99, University of Melbourne

Gale, B. and Branch, B. (1982). "Concentration Versus Market Share: Which Determines Performance and Why Does It Matter?” The Antitrust Bulletin, Spring 1982, pp. 83-105

Geroski, P. A. (1991). Market Dynamics and Entry. Oxford, Blackwell.

Harris, M.N. and Mátyás, L. (2000). "Performance of the Operational Wansbeek-Becker Estimator for Dynamic Panel Data Models”, Applied Economics Letters, 7(3), pp. 149-153.

Harris, M.N. and Mátyás, L. (1996). “A Comparative Analysis of Different Estimators for Dynamic Panel Data Models", Department. of Econometrics Working Paper no. 4/96, Monash University.

Harris, M.N., Mátyás, L. and Longmire, R. (1996). "The Robustness of Estimators for Dynamic Panel Data Models to Misspecification", Monash University, Dept. of Econometrics, Working Paper no. 9/96.

Hay, D. and Morris, D. (1991). Industrial Economics and Organisation. Oxford, Oxford University Press.

Hsiao, C. (1985). "Benefits and Limitations of Using Panel Data", Econometric Reviews, Vol. 4, pp. 121-174.

Hsiao, C. (1986). Analysis of Panel Data, Cambridge University Press, Cambridge, England.

Levy, D. (1987). “The Speed of the Invisible Hand", International Journal of Industrial Organisation, 5, pp. 79-92.

Liebowitz, S. J. (1982). "What Do Census Price-Cost Margins Measure?" Journal of Law and Economics, 25, pp. 231-246. 
Machin, S. and Van Reenen, J. (1993), "Profit Margins and the Business Cycle", The Journal of Industrial Economics, 41(1), pp. 29-50.

Martin, S (1993), Advanced Industrial Economics, Cambridge, Blackwells.

Mátyás, L. and Sevestre, P. (1996) eds., The Econometrics of Panel Data, Kluwer Academic Publishers, The Netherlands.

McDonald, J. T. (1999). "The Determinants of Firm Profitability in Australian Manufacturing”, Economic Record, 75(229), pp. 115-26.

Mueller, D. C. and Raunig, B. (1999), "Heterogeneities within Industries and StructurePerformance Models", Review of Industrial Organisation, 15: pp. 303-320.

Mundlak, Y. (1978a). "On the Pooling of Time Series and Cross Section Data", Econometrica, Vol. 46, pp. 69-85.

Mundlak, Y. (1978b). "Models With Varying Coefficients: Integration and Extension", Annales de l'INSEE, Vol. 30-31, pp. 483-509.

Nerlove, M. (1967). "Experimental Evidence on the Estimation of Dynamic Economic Relationships from a Time Series of Cross-Sections", Economic Studies Quarterly, Vol. 18 , pp. 42-74.

Nerlove, M. (1971). "Further Evidence on the Estimation of Dynamic Economic Relationships from a Time Series of Cross-Sections”, Econometrica, Vol. 39, pp. 359-387.

Nickell, S. (1981) Biases in Models with Fixed Effects, Econometrica, Vol. 49, pp. 1417-26.

Prince, Y. M. (1994). Price-cost margins in Dutch manufacturing: with an emphasis on cyclical and firm-size effects, Thesis Publishers, Amsterdam.

Ravenscraft, D. (1983). "Structure-Profit Relationships at the Line of Business and Industry Level”, Review of Economics and Statistics, 65, pp. 22-31.

Round, D. K. (1976). "Profitability and Concentration in Australian Manufacturing Industries, 1968-69 to 1972-73”, Economic Record, 52(138 521), pp. 228-38. 
Round, D. K. (1980a). "The Effect of Domestic and Foreign Competition on Performance in Australian Manufacturing Industries", Atlantic Economic Journal, 8, pp.62-74.

Round, D. K. (1980b). "The Determinants of Profitability and Tariffs in Australian Manufacturing", Malayan Economic Review, 25(2), pp. 63-80.

Scherer, F. M. and Ross, D. (1990). Industrial Market Structure and Economic Performance. Boston, Houghton Mifflin Company.

Sevestre, P. and Trognon, A. (1996). "Dynamic Linear Models", in The Econometrics of Panel Data, (chapter 7) Mátyás and Sevestre (eds.) (1996), Kluwer Academic Publishers, the Netherlands.

Shepherd, W. G. (1972). "The Elements of Market Structure." Review of Economics and Statistics, 54, pp. 25-37.

Tucker, K. A. (1977). Performance, Concentration and Structural Features in Retailing. Economics of the Australian Service Sector. London, Croom Helm.

Wansbeek, T. and Bekker, P. (1996). "On IV, GMM and ML in a Dynamic Panel Data Model", Economic Letters, 51(2), pp. 145-152. 
Current working papers from the 'Performance of Australian Enterprises' project

\begin{tabular}{|c|c|c|}
\hline Title & Number & Author(s) \\
\hline The Theory and Measurement of Profitability & $7 / 98$ & Gow/Kells \\
\hline The Definition and Measurement of Productivity & 9/98 & Rogers \\
\hline The Definition and Measurement of Innovation & $10 / 98$ & Rogers \\
\hline $\begin{array}{l}\text { Innovation in Australian Enterprises: Evidence from } \\
\text { the GAPS and IBIS databases }\end{array}$ & $19 / 98$ & Rogers \\
\hline $\begin{array}{l}\text { Productivity in Australian Enterprises: Evidence } \\
\text { from the ABS Growth and Performance Survey }\end{array}$ & 20/98 & Rogers \\
\hline Profitability in Australian Enterprises & $21 / 98$ & Feeny/Rogers \\
\hline $\begin{array}{l}\text { Performance of Australian Government Trading } \\
\text { Enterprises: An Overview }\end{array}$ & $22 / 98$ & Loundes \\
\hline $\begin{array}{l}\text { The Performance of Small and Medium Enterprises: } \\
\text { An Overview using the Growth and Performance } \\
\text { Survey }\end{array}$ & $1 / 99$ & Rogers \\
\hline $\begin{array}{l}\text { The Performance of Large Private Australian } \\
\text { Enterprises }\end{array}$ & $2 / 99$ & Feeny/Rogers \\
\hline $\begin{array}{l}\text { Labour Productivity in Australian Workplaces: } \\
\text { Evidence from the AWIRS }\end{array}$ & $19 / 99$ & Loundes \\
\hline $\begin{array}{l}\text { Market Share, Concentration and Diversification in } \\
\text { Firm Profitability }\end{array}$ & 20/99 & Feeny/Rogers \\
\hline $\begin{array}{l}\text { The Determinants of Corporate Effective Tax Rates: } \\
\text { Evidence from Australia }\end{array}$ & $21 / 99$ & Harris/Feeny \\
\hline $\begin{array}{l}\text { Determinants of Profitability: An Empirical } \\
\text { Investigation Using Australian Tax Entities }\end{array}$ & $01 / 00$ & Feeny \\
\hline $\begin{array}{l}\text { Understanding Innovative Firms: An Empirical } \\
\text { Analysis of the GAPS }\end{array}$ & $08 / 00$ & Rogers \\
\hline Import Competition and Labour Productivity & 09/00 & Bloch/McDonald \\
\hline $\begin{array}{l}\text { Analysing Firm-Level Labour Productivity Using } \\
\text { Survey Data }\end{array}$ & $10 / 00$ & Rogers/Tseng \\
\hline $\begin{array}{l}\text { Management and Industrial Relations Practices and } \\
\text { Outcomes in Australian Workplaces }\end{array}$ & $12 / 00$ & Loundes \\
\hline $\begin{array}{l}\text { Habit Persistence in Effective Tax Rates: Evidence } \\
\text { Using Australian Tax Entities }\end{array}$ & $13 / 00$ & Harris/Feeny \\
\hline
\end{tabular}


Title

Number

Author(s)

Foreign Competition, Foreign Ownership and Innovation in Australian Enterprises

20/00 Lofts/Loundes

Electronic copies of all working papers are available at:

http://www.ecom.unimelb.edu.au/iaesrwww/ep/p1.html 